\title{
The effect of digital marketing on the management of relationships with university students in times of Covid-19
}

\author{
Wagner Vicente-Ramos $^{\mathrm{a}^{*}}$ and Luz Mirella Cano-Torres ${ }^{\mathrm{a}}$
}

\begin{tabular}{l}
${ }^{a}$ Universidad Continental, Peru \\
\hline C H R O N I C L E \\
\hline Article history: \\
Received: June 21,2021 \\
Received in revised format: July \\
28,2021 \\
Accepted: October 19, 2021 \\
Available online: October 19, \\
2021 \\
\hline Keywords: \\
Digital marketing \\
Operational management \\
Analytical management \\
Collaborative management \\
Covid-19 \\
Students
\end{tabular}

\section{Introduction}

In a world increasingly saturated by advertising in traditional and digital channels, also under the context of pandemic, social networks became a little ally essential to adapt marketing strategies in a short time, generate content has become one of the biggest concerns of companies when it comes to establish contact with users (Kotler, 2019), digital marketing right now are one of the most efficient strategies in organizations and its success depends on how it is executed in the various business models of sale each company.

Digital marketing is an effective option for companies to find new strategies to reach customers who are increasingly digital because of uncertain environments. For Guillermo (2020) digital marketing should be understood as a system that applies marketing strategies that is carried out in digital media, either from an offline or digital business, that way we communicate with customers without selling them anything, because it is a form of forced but effective marketing. Also, Amson (2021), considers that, within the world of digital content marketing, especially the audiovisual that are consumed by users before the purchase decision, in addition Amson also mentions the video marketing and social media content as trends in the current year and that will endure as it attracts customers quickly, directly and emotionally. These new demands are superimposed on a closer relationship with customers considering the content they consume.

* Corresponding author.

E-mail address: wvicente@,continental.edu.pe (W. Vicente-Ramos)

(C) 2022 by the authors; licensee Growing Science, Canada. doi: $10.5267 /$ j.ijdns.2021.10.004 
According to Alqershi (2020), the size of the global market in relation to customers is constantly growing that is why the technology evolved adapting to the real needs of companies making what at first were doubts now are certainties, making references to CRM which is a tool that will customize the shopping experience of customers, getting that in the long-term customers are loyal and tend to be less sensitive to price and commercial stimuli of competitors.

In Peru, the retail sector, mass consumption and banking lead 19\% increase in digital advertising investment, although there are more and more people vaccinated, the pandemic and the fear of going out is still a constant threat and even without living the third wave of Covid-19, for these and many other reasons e-commerce would follow the path of growth as well as online advertising Management (2021). According to Enrique and Pineda (2019), today it is almost impossible to find a person who is not in a social network like Facebook, or who does not spend time chatting on WhatsApp among others, and thanks to the proliferation of smartphones a study was conducted in which Peru ranks first in scope of social media with $93.2 \%$, in this way also states that social networks and digital marketing tools influence social, economic and even ecological complexities, so that the industry in general has adapted to the new needs of the Peruvian market by offering digital solutions that provide information and timely attention in addition to comfort and modernity when acquiring a service. On the other hand, but no less important, $60 \%$ of the formal Mypes that use digital media bill almost twice as much thanks to the digital kit of the Ministry of Production, with the creation of this program, the administration seeks to raise sales of Mypes using nationwide all the tools available to the state so they can be more productive and thus help them migrate to formalization. Therefore, the use of digital tools and predictive analytics, will define a new sales channel that will allow the identification of customer tastes and the creation of new marketing and sales strategies. (Mejia, 2019).

Currently the education sector is recovering, after the blow they suffered at the beginning of the pandemic, private higher institutions had the great challenge of knowing if they were prepared to assume this new role of education in pandemic, the image that everyone has regarding public institutions is high quality, first class technology, demonstrating that they have a good management of digital marketing, but this was not seen during the beginning of the pandemic until the last 3 three months ago. This institution of higher education, located in the highlands of Peru and with more than 20 years of operation, showed that at the beginning of the pandemic they were not prepared technologically and digitally as thought, and this resulted in a decrease in the student body, as many of their students did not have a laptop at home or internet, considering that many of them are from very remote areas. There are factors such as poor communication with customers that affect the attention, inadequate use of digital media, caused students to show their dissatisfaction or even coming to withdraw from the institution, it is for that reason that it was proposed to determine the impact of digital marketing on the management relationship of university students in times of covid-19.

\section{Literature review}

\subsection{Digital Marketing}

If we go back a little and compare with the current marketing, we will see a drastic change from the way in how to reach end users to the way in which communication changes. Ramon (2021) mentions that digital marketing is a set of strategies or actions that are developed in media and internet channels, digital marketing involves establishing relationships and listen to what the customer or consumer needs, resulting in the emergence of a digital ecosystem that connects users 24 day and has shaped the new habits and behaviors of users.

For Krishen (2021), digital marketing is the application of data, ICT-based technology, media and devices to extend the reach of marketing in both the physical and virtual realm for the purpose of improving customer relationships by informing, influencing and engaging consumers. it helps to direct companies to their target audience, it is also mentioned that digital marketing should not be an exception for small organizations, as the tools are not exactly aimed at large companies. While it is true that digital marketing has been around for a long time, it has been applied with great intensity in recent years and the results of its application have been really considerable for companies because nowadays everyone has access to the internet and has a mobile device.

Digital marketing uses all forms of technology including artificial intelligence and the internet of things, in order to meet marketing objectives in both consumer-to-consumer and business-to-consumer environments. Bala (2018), believes that leaving companies free to be able to decide for change, is the right thing to do as they believe that digital marketing and communication still pursue the same objectives of knowing and understanding the needs of customers in order to respond efficiently seeking satisfaction and loyalty and for the achievement of this the tools, strategies, among others of digital marketing should be applied depending on the target group.

\subsubsection{Content Marketing}

According to Paradova (2020), defines content marketing as a strategy that is constantly increasing with technological advances and the development of the internet, the company publishes informative, educational, entertaining content and what content marketing does is the sum of all modern online marketing strategies and quality content is just one part of the whole content marketing cycle. 
Effective content marketing is a well-designed strategy, that is why for Al-Gasawneh and Al-Adamat (2020), content marketing often presents numerous details in their advertisements, which brings consumers to have a deeper understanding of the product and it should be taken into consideration that the results are often seen in a long term can be months or years.

\subsubsection{Social Media Marketing}

For Serajpour et al. (2021), social media marketing is one of the innovative and revolutionary marketing efforts in which consumers are engaged, under this subset of marketing, brands and consumers, without any limitation are connected/communicated with each other. Social media marketing refers to all those activities carried out in order to promote a brand through social media, which is at its peak. Also, Ibrahim, Aljarah and Ababneh (2020), consider social media marketing as a marketing tool of the future, as its impact is profound in front of consumers, also social media marketing is used by strategic marketers considering that it offers high visibility.

\subsection{Customer Relationship Management (CRM)}

Experts believe that converting a customer into a loyal customer is much cheaper than trying to get new customers and according to Ancheta et al. (2019), customer relationship management is the combination of practices, strategies and technologies that companies can use for the management and analysis of customer interactions and data throughout the relationship with the company in order to improve customer service and retention relationships and thus boost sales.

Also, for Soltani et al. (2018), CRM focuses on improving, maintaining and establishing long-term relationships with customers and the recent emergence of CRM systems is a big help for the company as it focuses more on the value of customer data as a key asset of the organization and this leads to an improvement in the company's relationship with customers.

Finally, Guerola et al. (2020) consider that customer relationship management is a customer-oriented strategy and that this means listening to them wherever they want and wherever they are, understanding them in their decisions and learning as much as possible to give them what they want so that they discard any intention of going to the competition.

\subsubsection{Operational CRM}

For Khlif (2021), the operational CRM can provide the company with a complete view of each of the interactions of all customers, thereby streamline, automate and improve the business procedures of a company. When we talk about operational CRM refers to facilitate the tasks to customers through different media such as e-mail, web, mobile phone, etc. Trying to respond and at the same time creating affective and lasting ties through the means used.

\subsubsection{Collaborative CRM}

According to Patil (2020), collaborative CRM serves to share customer information among employees, collaborative customer relationship management focuses on pursuing this goal to improve customer service, increase customer satisfaction and improve the process of customer acquisition and retention. In addition, collaborative CRM improves company-customer interaction, establishes multi-channel communication across different areas of the company, makes managers more efficient, and eliminates duplication of tasks in the initial data entry.

\subsubsection{Analytical CRM}

Analytical CRM is a systematic approach to analyzing customer data and interactions for the purpose of improving the processes involved in sales, marketing and customer service. For Al-Homery et al. (2019), the main objective of analytical CRM is to collect customer information from various channels to know their buying behavior and buying habits, also applying analytical CRM will achieve higher lead conversion rate, improve customer experience, increase customer loyalty and satisfaction and get more accurate financial forecasting and planning.

\section{Research model and hypothesis}

For the Digital Marketing construct, the following indicators and questions were considered based on Fiorella's (2021) research:

a) Content Marketing (CM): The design of the university website is attractive enough to stay on it (CM1), navigating on the university website is a pleasant experience (CM2), when visiting the university website I found adequate information (CM4), the information contained on the website is useful (CM5) and I would recommend the use of the website if I need information about the university (CM6).

b) Marketing in social networks (MR): The content that the university publishes in social networks is attractive (MR2), when asked I would recommend the university's social network (MR3), I encourage people to follow the university's social networks (MR4), I am satisfied with the university's social networks (MR5) and I like, share, react and comment on the university's publications in social networks (MR6). 
The construct of relationship management with university students consisted of the following indicators and their respective questions:

a) Operational management of relations with university students (CRM O): I receive agile and personalized attention from the university through its website or social networks (CO1), the university responds quickly to complaints or suggestions made through its website or social networks (CO2), I know that various areas or departments work to keep the website or fan page updated (CO3) and the website and/or social network of the university are updated.

b) Collaborative Relationship Management with university students (CRM C): The university's various platforms generate a pleasant user experience (CC1), I know the university's various platforms (CC2), the university's website is interactive and self-responsive (CC3), and the website's color scheme and/or contrast are appropriate (CC4).

c) Analytical management of relationships with university students (CRM A): Metrics or ratios of visits to the website are shown (CA1), the website suggests content based on the visits and actions that are performed (CA2), the web page or fan page asks me for personal data to access its contents (CA3) and there are personalized campaigns on the web or on social networks (CA4).

From which the following conceptual model and hypotheses are established.

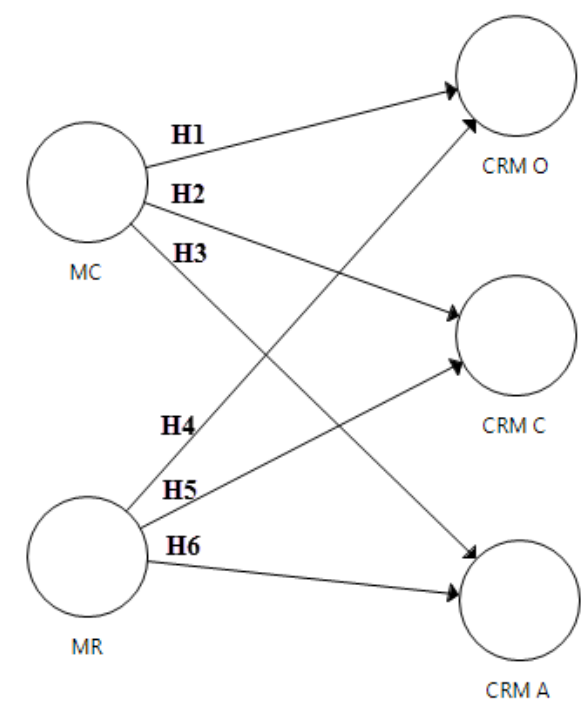

Fig. 1. Conceptual model and hypotheses

$\mathbf{H}_{1}$ : Content Marketing (CM) positively influences the operational management of relationships with university students (CRM $O)$.

H2: Content Marketing (CM) positively influences Collaborative Relationship Management with university students (CRM $C)$.

H3: Content Marketing (CM) positively influences analytical relationship management with university students (CRM A).

$\mathbf{H}_{4}$ : Social Media Marketing (SM) positively influences operational relationship management with university students (CRM $O)$.

H5: Social Media Marketing (SM) positively influences collaborative relationship management with university students (CRM $C)$.

H6: Social Media Marketing (SM) positively influences analytical relationship management with university students (CRM A).

\section{Method}

The present study applied the deductive inferential scientific method, for which the type and level of applied and explanatory research was used respectively, since it is intended to measure the causal link that exists between the variables of study. Likewise, the research design used is the non-experimental cross-sectional design.

\subsection{Population and sample}

The population is constituted by the students of the Institution of higher education of the city of Huancayo, which are more than 10,000. The sample size was 439 individuals made up of males (49.9\%) and females (50.1\%), with an age range of 18 37 years, considering all professional careers who were under study. Considering with an allowed margin of error of $5 \%$, a factor of "p" of 0.5 and "q" of 0.5 , confidence level of $95 \%$. 


\subsection{Data collection instrument}

Questionnaires were designed and applied to students of the university study center in the city of Huancayo. The structure of the instrument presents 12 items for the variable digital marketing (six of content marketing and six of social media marketing) and 12 items for the variable customer relationship management-CRM (four of operational CRM, four of collaborative CRM and four of analytical CRM). For the validation of the instrument, the validation form was used by expert criteria, and the reliability was determined through the Cronbach's Alpha coefficient.

\section{Results}

\subsection{Assessment of the Measurement Model}

Table 1 shows the measurement analysis of the model, based on the reliability and validity of the measurement scales. Regarding reliability, the internal consistency of the scales is evidenced through the Cronbach Alpha value (between 0.721 to 0.832 ) and the composite reliability (between 0.852 to 0.882 ). Regarding convergent validity, all factor loadings are above 0.659. Likewise, all scales have average variance extracted (AVE) percentages greater than $50 \%$. The discriminant validity of the construct was approved by the criteria of Fornell Larcker, which verifies the independence of each of the scales, considering that the square root of the AVE is greater than the correlations with the rest of the scales. In all cases, the assumption was fulfilled.

Table 1

Results of the model measurement analysis

\begin{tabular}{cccccc}
\hline Variables & $\begin{array}{c}\text { Cronbach } \\
\text { alpha }\end{array}$ & $\begin{array}{c}\text { Composite re- } \\
\text { liability }\end{array}$ & $\begin{array}{c}\text { Factor loads } \\
\text { (range) }\end{array}$ & $\begin{array}{c}\text { Average variance } \\
\text { extracted (AVE) }\end{array}$ & $\begin{array}{c}\text { Discriminant } \\
\text { Validity }\end{array}$ \\
\hline MC & 0.783 & 0.852 & $0.659-0.810$ & 0.536 & 0.732 \\
MR & 0.832 & 0.882 & $0.746-0.810$ & 0.599 & 0.774 \\
CRM O & 0.802 & 0.871 & $0.722-0.826$ & 0.629 & 0.793 \\
CRM C & 0.721 & 0.827 & $0.690-0.770$ & 0.545 & 0.738 \\
CRM A & 0.771 & 0.853 & $0.734-0.799$ & 0.593 & 0.770 \\
\hline
\end{tabular}

As shown in Fig. 2, in all cases an $\mathrm{R}^{2}$ greater than 0.500 was obtained, which is highly significant, showing that the model significantly explains the variance of the conceptual constructs of the dependent variable.

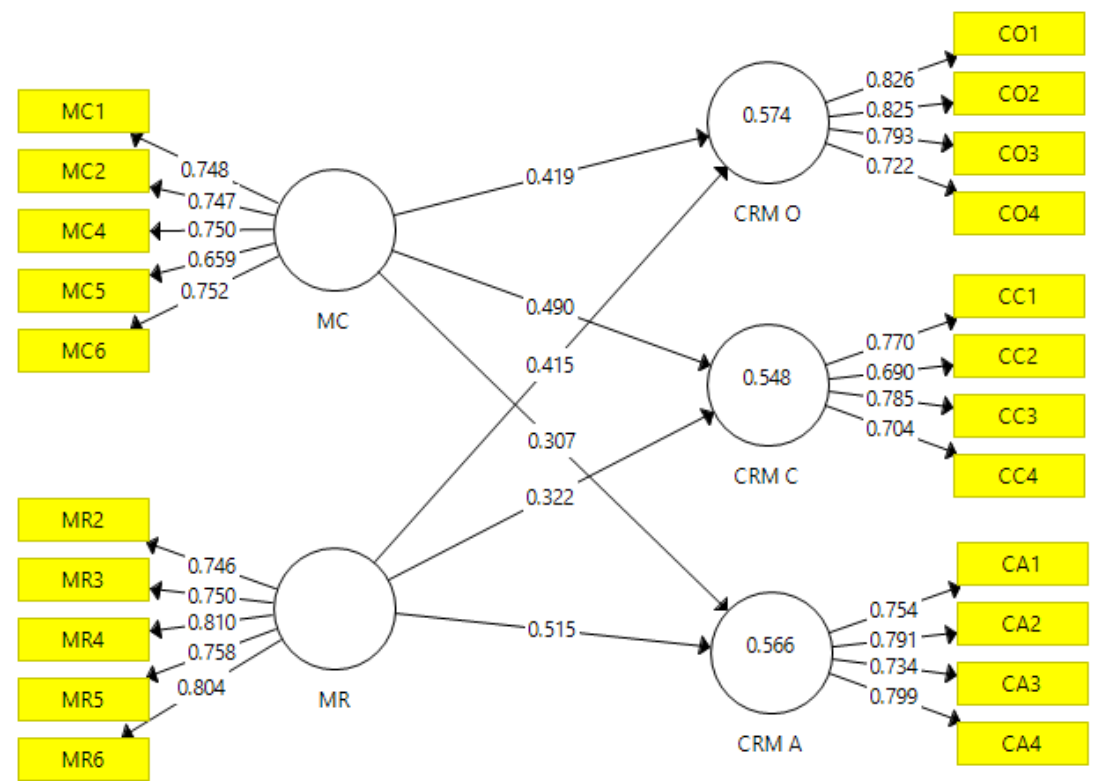

Fig. 2. Results for the hypothetized model with structural equations.

\subsection{Assessment of the Structural Model}

After checking the validity and reliability of the measurement model, the relationships of the constructs were tested. Hypotheses were tested by examining the road coefficients and their significance levels. Bootstrapping was performed with 6000 subsamples to verify the statistical significance of each of the road coefficients (Oré-Calixto \& Vicente-Ramos, 2021). Fig. 3 shows the estimated path of the PLS analysis. 


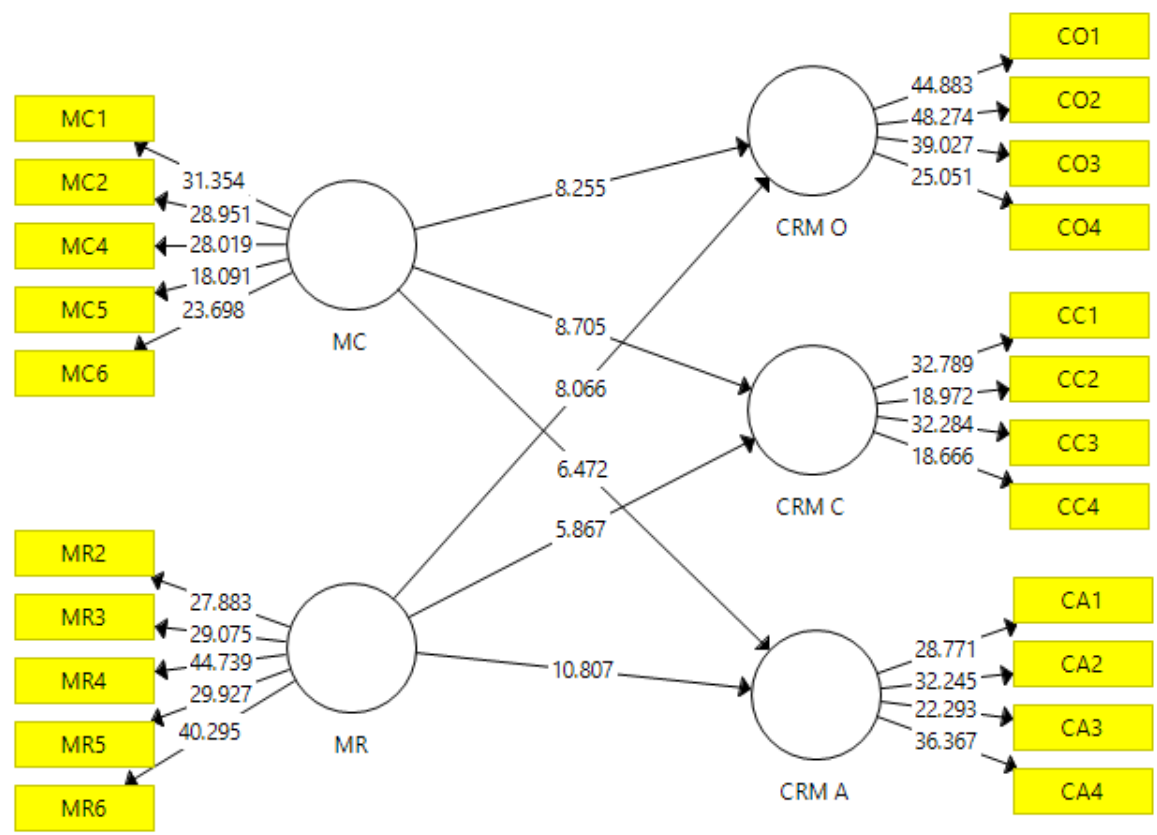

Fig. 3. Digital Marketing and Customer Relationship Management Modeling

Table 2 shows the contracting of results, where the 6 hypotheses are accepted $(\mathrm{p}<0.05)$

Table 2

Results of the model structure analysis

\begin{tabular}{|c|c|c|c|c|c|}
\hline Hypotheses & Mean sample & $\begin{array}{c}\text { Standard devia- } \\
\text { tion }\end{array}$ & Beta & p value & Decision \\
\hline $\mathrm{MC} \rightarrow \mathrm{CRM} \mathrm{O}$ & 0.419 & 0.051 & 8.255 & 0.000 & Accept $\mathrm{H}_{1}$ \\
\hline $\mathrm{MC} \rightarrow \mathrm{CRM} \mathrm{C}$ & 0.487 & 0.056 & 8.705 & 0.000 & Accept $\mathrm{H}_{2}$ \\
\hline $\mathrm{MC} \rightarrow \mathrm{CRM} \mathrm{A}$ & 0.307 & 0.047 & 6.472 & 0.000 & Accept $\mathrm{H}_{3}$ \\
\hline $\mathrm{MR} \rightarrow \mathrm{CRM} \mathrm{O}$ & 0.415 & 0.051 & 8.066 & 0.000 & Accept $\mathrm{H}_{4}$ \\
\hline $\mathrm{MR} \rightarrow \mathrm{CRM} \mathrm{C}$ & 0.324 & 0.055 & 5.867 & 0.000 & Accept $\mathrm{H}_{5}$ \\
\hline $\mathrm{MR} \rightarrow \mathrm{CRM} \mathrm{A}$ & 0.516 & 0.048 & 10.655 & 0.000 & Accept $\mathrm{H}_{6}$ \\
\hline
\end{tabular}

\section{Discussion and conclusion}

\section{Regarding the influence of content marketing (CM) on the operational management of relations with university stu-} dents (CRM O)

In the study, it was found that content marketing has a positive impact on customer relationship management operations. These results are in line with those of Zhou et al. (2021), who claim that content marketing strategy positively influences influencer marketing strategy by addressing the problems of cultural barriers, commercialized content and sponsorship disclosure. Given this paradigm, it is essential to analyze the effects of published content from universities on both users and organizations, who should adapt the content marketing strategies used to promote the interaction of their audience. It is concluded that content marketing did have a significant impact on the proper management of customer relations at the operational level, since the digital media used by the Higher Institution as its website, were attractive for the agile personalized attention, improving communication that is so necessary in these times of virtual development.

\section{Regarding the influence of content marketing $(\mathrm{CM})$ on collaborative relationship management with university students (CRM C)}

The research results show that content marketing has a great impact on collaborative customer relationship management. These results are in term with those of Gregoriades et al. (2021), who state that the digital content strategy positively influences messaging through decision trees, presenting a machine learning approach that includes electronic word of mouth. Given this new paradigm, it is required to analyze the results of the marketing campaign strategies applied by the institution, thus improving the design of messages to better respond to the desires and needs of users, regaining the trust of students through better service. It is concluded that the content marketing does have a significant impact on the measured management of 
relationships with customers at a collaborative level, since the information published in their networks is clear and concise, generating an experience and increasing their trust.

Regarding the influence of content marketing (CM) on analytical relationship management with university students (CRM A)

In the study, it was found that content marketing has a positive impact on analytical customer relationship management. Likewise, Hua et al. (2021), points out that content marketing positively influences the purchase of supplement packaging as it is required to analyze the types of marketing claims contained in these packages. Similarly, Müller and Christandl (2019), question the effect of content marketing on sponsored content and user-generated content and the study examines how different types of content are perceived and how they influence brand responses through persuasion knowledge by developing a serial mediation model, which postulates that different types of content lead to varying conceptual persuasion knowledge, which then influences the activation of attitudinal persuasion knowledge and, in turn, results in different attitudes towards the brand. It is concluded, that Content Marketing does impact significantly on the correct management of customer relations at the analytical level, since the information on the website of the higher education institution is of necessity and understandable to all audiences, in addition to having easily accessible means of contact that is considered a help to users to communicate whether the case of their situation and all this helps the study center to analyze its metrics or ratios of visits and interactions of its website, thus preventing users from misinterpreting the information provided.

Regarding the influence of social media marketing (SM) on the operational management of relations with university students (CRM O)

Social media marketing significantly influences operational customer relationship management. Sedalo, Boateng and Kosiba (2021), conducted a study looking for them the necessary information since this is a topic with little information, in which they state that the affordability of social media the use and its efficiency have influenced the relationship marketing practices, obtaining three possibilities that social media consider that is brand visibility, sharing and relating obtaining as a result customer acquisition. It is concluded, that Social Media Marketing does relate significantly to the measured customer relationship management at the operational level, as the institution responds quickly to complaints or suggestion made by users through their social networks or their website, understanding that social networks are easy to identify and that their content is tractive because it is of social and educational interest.

Regarding the influence of social media marketing (SM) on Collaborative Relationship Management with university students (CRM C)

Social media marketing significantly influences collaborative customer relationship management. For Chawla and Chodak (2021), social media marketing in companies have influenced organic website promotions on Facebook. The identification of these factors show that a web link placed in the comments of a Facebook post, rather than the caption, is more lucrative. It is also shown that, depending on the objectives of the campaign, these metrics can give valuable information about the optimal time to post, as well as the interval between posts. It is concluded, that Social Media Marketing does relate significantly to proper customer relationship management at a collaborative level, as users are aware of the various platforms of the higher education institution and would recommend the institution's social network because the same users promote more people to follow the various social networks of the higher education institution.

Regarding the influence of social media marketing (SM) on analytical relationship management with university students (CRM A)

Social media marketing significantly influences analytical customer relationship management . These results are in line with Dolega, Rowe and Branagan (2021), who investigated the impact of social media marketing and its influence on traffic, orders and sales, obtaining the revelation of the results mentioning that the largest social media is Facebook being an effective channel, also the effectiveness of social media marketing varies according to the products or services offered for sale. Taken together, these results offer a better understanding of the ways in which social media marketing impacts businesses and provide insights on how to allocate resources to develop marketing campaigns. It is concluded, that Social Media Marketing does significantly impact on proper customer relationship management at the analytical level, as in social media management is made known to college students that the information displayed and requested on social media are to provide better service, also revealed that trust mediated the effects of experience, authenticity and homophily on loyalty and marketing results.

\section{References}

Al-Gasawneh, J., Al-Adamat, A. (2020). The mediating role of e-word of mouth on the relationship between content marketing and green purchase intention. Management Science Letters, 10(8), 1701-1708.

Al-Homery, H., Asharai, H. y Ahmad, A. (2019). The Core Components and Types of CRM Pakistan Journal of Humanities and Social Sciences, 7(1), 121-145. 
Alqershi, N. M. (2020). Innovative CRM and performance of SMEs: The moderating role of relational capital. Journal of Open Innovation: Technology, Market, and Complexity, 1-18.

Amson, A. R. (2021). Exploring the extent of digital food and beverage related content associated with a family-friendly event: a case study. BMC Public Health.

Ancheta, D., Bautista, L., Estrada, A. \& Intal, G. (2019). EyEstate: Customer relations management system with sale data visualization and $360^{\circ}$ virtual tour technology. 2019 The 3rd International Conference on Software and e-Business, (1116) doi: $10.1145 / 3374549.3374580$

Bala, M. (2018). A critical review of digital marketing. International Journal of Management, IT \& Engineering, 8(10), 321339.

Chawla, Y., \& Chodak, G. (2021). Social media marketing for businesses: Organic promotions of web-links on Facebook. Journal of Business Research, 135, 49-65.

Dolega, L., Rowe, F., \& Branagan, E. (2021). Going digital? The impact of social media marketing on retail website traffic, orders and sales. Journal of Retailing and Consumer Services, 60, 102501.

Enrique Tica, G. I., \& Pineda Ruiz, D. A. (2018). El marketing digital en las redes sociales facebook, linkedin y youtube y su influencia en la fidelización de los clientes de la empresa Atanasovski corredores de seguros.

Gestión. (junio del 2021). Gestión. Obtenido de Gestión: https://gestion.pe/economia/iab-peru-retail-consumo-masivo-ybanca-lideran-alza-de-19-en-inversion-publicitaria-digital-noticia/?ref=gesr

Gregoriades, A., Pampaka, M., Herodotou, H., \& Christodoulou, E. (2021). Supporting digital content marketing and messaging through topic modelling and decision trees. Expert systems with applications, 184, 115546.

Guerola, V., Oltra, R., \& Gil, H. (2020). Análisis de la relación entre el grado de introducción de CRM y los beneficios de la empresa a través del Desempeño Organizacional y la Innovación Empresarial. Investigación y pensamiento crítico, 9(1), 67-87.

Guillermo, N. d. (2020). The impact of digital marketing on manufacturing companies. Revista Iberoamericana de contaduría, economía y administración.

Hua, S. V., Granger, B., Bauer, K., \& Roberto, C. A. (2021). A content analysis of marketing on the packages of dietary supplements for weight loss and muscle building. Preventive Medicine Reports, 23, 101504.

Ibrahim, B., Aljarah, A., Ababneh B. (2020). ¿Do social media marketing activities enhance consumer perception of brands? A meta-analytic examination. Journal of Promotion Management, 6(4), 544-568.

Khlif, H. (2021). Factors for Success in Customer Relationship Management (CRM) Systems. World Academics Journal of Management, 9(1), 16-20.

Kotler. (2019). Asian Competitors: Marketing for Competitiveness in the Age of Digital Consumers. WSPC.

Krishen, A. S., Dwivedi, Y. K., Bindu, N., Kumar, K. S. (2021). A broad overview of interactive digital marketing: A bibliometric network analysis. Journal of Business Research, 131(C), 183-195.

Mejía, G. C. M. (2019). Como diseñar una sesión de aprendizaje para una clase de marketing digital, "El Inbound Marketing" para alumnos de la carrera de marketing de la universidad UTP, Lima-Perú.

Müller, J., \& Christandl, F. (2019). Content is king-But who is the king of kings? The effect of content marketing, sponsored content \& user-generated content on brand responses. Computers in Human Behavior, 96, 46-55.

Oré-Calixto, S., \& Vicente-Ramos, W. (2021). The effect of digital marketing on customer relationship management in the education sector: Peruvian case. Uncertain Supply Chain Management, 9(3), 549-554.

Patil, J. S. (2020). Customer Analytics Improves Banks Performance: A Descriptive Study of Analytical CRM among Private, Cooperative and Nationalised Banks. Test Engineering \& Management, 83(1), 10464-10470

Poradova, M. (2020). Content marketing strategy and its impact on customers under the global market conditions. SHS Web of Conferences, (Vol. 74, p. 01027).

Ramón, J. (2021). Using data sciences in digital marketing: Framework, methods, and performance metrics. Journal of Innovation \& Knowledge, 6(2), 92-102.

Sedalo, G., Boateng, H. y Kosiba, JP (2021). Exploring social media affordance in relationship marketing practices in SMEs. Journal Pre-proof, 100017.

Serajpour, S., Fattahi, M., Zameni, F. (2021). The impact of social network marketing on consumer Willingness for brand purchase, given the mediating role of customer engagement. Revista de economía resistiva, 9(1), 67-81.

Soltani, Z., Zareie, B., Milani, F. \& Navimipour, N. (2018). The impacto f the customer relationship management on the organization performance. The Journal of High Technology Management Research, 29(2), 237-246.

Zhou, S., Blazquez, M., McCormick, H., \& Barnes, L. (2021). How social media influencers' narrative strategies benefit cultivating influencer marketing: Tackling issues of cultural barriers, commercialised content, and sponsorship disclosure. Journal of Business Research, 134, 122-142.

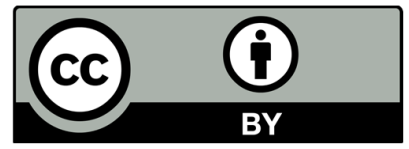

(C) 2022 by the authors; licensee Growing Science, Canada. This is an open access article distributed under the terms and conditions of the Creative Commons Attribution (CC-BY) license (http://creativecommons.org/licenses/by/4.0/). 